\title{
EKSTRAK ETANOL MORINGA OLEIFERA LAM TERHADAP FOLIKULOGENESIS PADA MENCIT MODEL ENDOMETRIOSIS
}

\author{
Rila Rindi Antina ${ }^{* 1}$, Hendy Hendarto ${ }^{2}$, Widjiati $^{3}$ \\ ${ }^{1}$ Mahasiswa Magister Ilmu Kesehatan Reproduksi, Fakultas Kedokteran, Universitas \\ Airlangga Surabaya \\ ${ }^{2}$ Departemen Obstetri dan Ginekologi, Fakultas Kedokteran, Universitas Airlangga, \\ RSUD Dr. Soetomo \\ ${ }^{3}$ Departemen Embriologi Veteriner, Fakultas Kedokteran Hewan, Universitas Airlangga \\ Email : rila.rindi@gmail.com
}

\begin{abstract}
Abstrak
Endometriosis didefinisikan sebagai adanya jaringan endometrium di luar rahim. Peningkatan konsentrasi sitokin inflamasi dan faktor pertumbuhan di dalam cairan peritonium berkontribusi pada pembentukan lesi peritonium. Faktor pertumbuhan berperan selama folliculogenesis. Moringa oleifera kaya akan flavonoid. Kuercetin dan kaempferol adalah flavonoid, senyawa dengan gugus hidroksil fenolik dengan aksi antioksidan yang memiliki kegunaan potensial terapeutik. Penelitian ini untuk membuktikan adanya pengaruh pemberian ekstrak etanol daun kelor (Moringa oleifera Lam) terhadap folikulogenesis pada mencit (Mus musculus) model endometriosis. Metode penelitian menggunakan mencit (Mus musculus) 20-25g yang dibagi menjadi dua kelompok, yaitu kelompok kontrol endometriosis dan kelompok perlakuan diberi ekstrak etanol daun kelor 0,35 mg/gBB selama 14 hari. Jaringan ovarium dilakukan pemeriksaan histopatologi dengan pengecatan hematoxylin-eosin. Hasil penelitian menunjukkan terdapat perbedaan yang signifikan $(\rho<0,05)$ jumlah folikel primer, jumlah folikel sekunder, jumlah folikel tersier, jumlah folikel de graaf pada kelompok kontrol dan kelompok perlakuan. Kesimpulan Penelitian menunjukkan ekstrak etanol daun kelor meningkatkan folikulogenesis pada mencit model endometriosis
\end{abstract}

Kata kunci-Ekstrak etanol daun kelor, folikulogenesis, endometrosis 


\begin{abstract}
Endometriosis is defined as the presence of endometrial tissue outside the uterus. The increased concentration of inflammatory cytokines and growth factors in contributing to the formation of the peritoneum liquid lesions peritoneum. Growth factor plays a role during folliculogenesis. Moringa oleifera is rich in flavonoids. Quercetin and kaempferol are flavonoids, compounds with hydroxyl phenolic antioxidant action with that have potential therapeutic uses. This research to prove the existence of the influence of ethanol extracts of leaves of granting Moringa oleifera Lam against folliculogenesis in mice (Mus musculus) model of endometriosis. Research method using mice (Mus musculus) 20-25 g are divided into two groups, namely the control group and the Group's treatment of endometriosis was given ethanol extracts of leaves of the Moringa oleifera $0.35 \mathrm{mg} / \mathrm{gBB}$ for 14 days. Ovarian tissue histopathology examination is performed with hematoxylin-eosin staining. The results showed there was a significant difference ( $\rho$ < $0.05)$ the number of primary follicles, the number of secondary follicles, the number of tertiary follicles, the number of follicles de Graaf between the control group and treatment group. The conclusion the research indicates ethanol extracts of leaves of Moringa oleifera increased folliculogenesis on mice model of endometriosis
\end{abstract}

Keywords-Ethanol extracts of leaves of Moringa oleifera, folliculogenesis, endometriosis 


\section{PENDAHULUAN}

Endometriosis didefinisikan sebagai adanya jaringan endometrium di luar rahim. Etiologi endometriosis tidak pasti, kombinasi genetik, hormonal, imunologis dan faktor anatomi berkontribusi pada pembentukan dan perkembangan lesi endometrium (Giudice dan Kao, 2004; Young et al., 2013).

Endometriosis

diperkirakan mempengaruhi wanita usia subur sekitar 6$10 \%$ dan berhubungan dengan nyeri panggul kronis, dismenorea dan subfertilitas (Giudice and Kao 2004; Meuleman et al., 2009). Kejadian endometriosis yang telah dilaporkan per tahun sebesar $0,1 \%$ antara wanita berusia 15-49 tahun (Vercellini et al., 2014). Prevalensi endometriosis pada wanita dengan infertilitas sangat tinggi, mencapai hampir 50\% (Matarese et al., 2003).

Peningkatan konsentrasi sitokin inflamasi dan faktor pertumbuhan (growth factors) di dalam cairan peritonium dan jaringan peritonium dianggap berkontribusi pada pembentukan lesi peritonium (Young et al., 2013). Beberapa hasil penelitian juga menunjukkan bahwa perubahan ekspresi dan signaling TGF- $\beta$ dapat berkontribusi pada patofisiologi endometriosis (Pizzo et al., 2002; Young et al., 2014; Young et al., 2017).

Transforming growth factor beta (TGF- $\beta$ ) adalah faktor pertumbuhan inflamasi yang mengatur berbagai fungsi seluler termasuk adesi sel, invasi dan angiogenesis yang semuanya sangat penting selama pengembangan lesi endometriosis (Pizzo et al., 2002; Young et al., 2014). Faktor pertumbuhan (growth factors) berperan penting selama perkembangan ovarium awal dan folliculogenesis, karena faktor pertumbuhan (growth factors) mengatur migrasi germ sel ke gonad (Yang et al., 2013). Faktor pertumbuhan (growth factors) juga bekerja pada perekrutan folikel, proliferasi atau atresia sel granulosa dan teka, steroidogenesis, pematangan oosit, ovulasi dan luteinisasi (Dunlop dan Anderson, 2014). Di antara growth factors, anggota superfamili transforming growth factor beta (TGF- $\beta$ ) dianggap penting untuk pengembangan folikuler (Hsueh et al., 2014; Piotrowska et al., 2013). Beberapa anggota superfamili transforming growth factor beta (TGF- $\beta$ ) yang berperan dalam folikulogenesis diantaranya adalah growth differentiation factor 9 dan bone morphogenetic protein 15 (Peng et al., 2013; Hendarto et al., 2010) serta aktivin yang berperan dalam interaksi intrafolikuler (Pauklin dan Vallier, 2015; Robertson et al., 2004)

Berdasarkan hasil pengamatan ini, diperkirakan bahwa lingkungan lokal intrafolikular mungkin secara negatif dipengaruhi oleh faktor-faktor yang berhubungan dengan endometriosis. Beberapa penelitian telah menjelaskan bagaimana mekanisme molekuler bahwa endometriosis dapat mempengaruhi pertumbuhan, steroidogenesis dan fungsi sel granulosa (GCs). Integrasi antara oosit dan GC-nya sangat penting untuk menentukan waktu dimulainya kembali meiosis dan kejadian yang akan terjadi pada embrio setelah fertilisasi (Sanchez $e t$ al., 2016).

Saat ini, pengobatan untuk endometriosis terutama terdiri dari terapi menopause semu dan terapi pseudocyesis yang paling banyak digunakan (Platteeuw dan D'Hooghe, 2014). Endometriosis yang ditangani secara operasi atau pengobatan medis gejalanya bisa kambuh hingga $75 \%$ dari seluruh kasus dan perawatan medis 
yang tersedia masih memiliki efek samping yang tidak diinginkan (Jacobson et al., 2009).

Di Asia, Moringa oleifera kaya akan kuersetin dan kaempferol. Kuercetin dan kaempferol adalah flavonoid, senyawa dengan gugus hidroksil fenolik dengan aksi antioksidan yang memiliki kegunaan potensial terapeutik (Ferreira et al., 2008). Kuercetin secara signifikan menghambat ekspresi reseptor TGF- $\beta 1$ dan 2 pada fibroblas keloid pada konsentrasi rendah, sedang, dan tinggi (Phan et al., 2004). Ekstrak etanol Moringa oleifera secara signifikan mengurangi kenaikan $\mathrm{TNF}-\alpha$ dan TGF- $\beta$ pada tikus albino fibrosis hati yang diinduksi thiacemide (Moustafa et al., 2015).

Berdasarkan komponen bioaktif yang terkandung didalam ekstrak etanol (Moringa oleifera Lam), penggunaannya untuk pengobatan endometriosis dapat digunakan namun penelitian mengenai pengaruh ekstrak daun kelor (Moringa oleifera Lam) terhadap endometriosis belum banyak dilakukan, atas dasar hal tersebut dilakukan penelitian tentang folikulogenesis pada ovarium dengan endometriosis. Hasil dari penelitian ini diharapkan sebagai upaya pembaharuan terhadap upaya preventif terhadap infertilitas karena proses perubahan siklus sel granulosa yang mengakibatkan gangguan folikulogenesis, sehingga dirasa perlu untuk meneliti pengaruh ekstrak etanol daun kelor (Moringa oleifera Lam) terhadap ekspresi aktivin dan folikulogenesis pada mencit (Mus musculus) model endometriosis.

\section{TINJAUAN PUSTAKA}

Endometriosis adalah penyakit inflamasi yang bergantung pada estrogen yang mempengaruhi 5 sampai $10 \%$ wanita usia subur. Endometriosis juga didefinisikan dengan adanya jaringan 
Jurnal Biosains Pascasarjana Vol. 19 (2017) pp

(C) (2017) Sekolah Pascasarjana Universitas Airlangga, Indonesia

seperti endometrium di situs luar rongga

uterus, terutama pada peritoneum pelvis dan ovarium. Klinis utama endometriosis adalah kelainan panggul kronis, nyeri saat bersenggama, dan infertilitas (Giudice dan Kao, 2004). Endometriosis diperkirakan mempengaruhi wanita usia subur sekitar 6$10 \%$ dan berhubungan dengan nyeri panggul kronis, dismenorea dan subfertilitas (Giudice and Kao, 2004; Meuleman et al., 2009).

Angka prevalensi dan kejadian endometriosis tergantung pada hasil visualisasi lesi pada proses pembedahan yang mahal dan prosedural invasif untuk mendiagnosis secara pasti. Perkiraan prevalensi endometriosis sulit ditemukan (Vercellini et al., 2014; Allaire, 2006). Perkiraan prevalensinya menunjukkan bahwa endometriosis mempengaruhi 10\%$15 \%$ dari semua usia wanita reproduksi (Allaire, 2006). Prevalensinya sekitar 5\%, mencapai puncaknya antara usia 25 tahun sampai dengan 35 tahun. Kejadian endometriosis yang telah dilaporkan per tahun sebesar $0,1 \%$ antara wanita berusia 15-49 tahun (Vercellini et al., 2014). Endometriosis dianggap sebagai salah satu penyakit ginekologi yang paling sering terjadi, yang mempengaruhi wanita dalam kehidupan reproduksinya sebesar 15-20\%. Prevalensi endometriosis pada wanita dengan infertilitas sangat tinggi, mencapai hampir 50\% (Matarese et al., 2003).

Tiga bentuk endometriosis yang berbeda secara klinis adalah implan endometriotik pada permukaan peritoneum pelvis dan ovarium (peritonium endometriosis), ovarium kista yang dilapisi oleh mukosa endometrioid (endometrioma) dan massa padat yang kompleks terdiri dari jaringan endometriotik (jaringan adiposa dan fibromuskular) berada diantara rektum dan vagina (rectovaginal endometriotic nodule). Tiga bentuk endometriosis 
tersebut mungkin merupakan varian dari proses patologis yang sama atau juga dapat disebabkan oleh mekanisme yang berbeda (Garry, 2004; Brosens, 2004).

Setelah attachment, sel endometrium ektopik harus menyerang lingkungan peritonium untuk membangun diri sebagai lesi. Investigasi menggunakan jaringan endometrium dan peritonium dari pasien dengan dan tanpa endometriosis terjadi peningkatan invasi potensi sel stroma endometrium dari pasien dengan endometriosis (Shi et al., 2011). Invasi mesothelium dapat difasilitasi oleh matriks metaloprotease (MMPs) sekelompok protein kolagenase yang mampu mencerna dan memodernisasi ECM. MMPs diekspresikan dalam endometrium dan telah terbukti terdapat dalam cairan peritoneum dan lesi endometriotik (Gilabert-Estelle's et al., 2007; Sotnikova et al., 2010; Itoh et al., 2012).

Gambaran histologis endometriosis adalah adanya sel stroma atau epitel endometrium, perdarahan kronis, dan tanda-tanda peradangan. Lesi endometriosis dapat terjadi secara tunggal atau kombinasi dan berhubungan dengan peningkatan risiko infertilitas atau nyeri pelvis kronis (Bulun, 2009). Peradangan yang terlibat dalam endometriosis dapat merangsang ujung saraf di panggul dan dengan demikian menyebabkan rasa sakit, merusak fungsi rahim, mengurangi reseptivitas endometrium dan menghambat perkembangan oosit dan embrio (Berkley et al., 2004; Banhardt et al., 2002).

Pengaruh parakrin intraovarian sangat penting untuk modulasi oosit, pertumbuhan dan pematangan folikel dan memberikan sensitifitas yang cukup terhadap stimulasi gonadotropin. Signalling antara oosit dan GCs belum sepenuhnya dipahami namun dalam beberapa tahun terakhir beberapa sinyal sudah dapat diidentifikasi beserta karakteristik fungsinya. Dalam konteks parakrin intraovarian, beberapa anggota transforming growth factor beta (TGF- $\beta$ ) superfamili diketahui memainkan peran penting (Sanchez et al., 2016). TGF- $\beta$ adalah peptida yang diproduksi secara eksklusif oleh GCs pada folikel pre-antral dan folikel antral kecil yang tumbuh, peptida ini berfungsi untuk menjaga ketenangan mereka (Sanchez et al., 2013).

BMP adalah subfamili terbesar dari superfamili TGF- $\beta$ dan bertindak sebagai regulator utama aktivasi folikel, perkembangan, proliferasi dan steroidogenesis (Abir et al., 2008). Ekspresi dari mRNA atau protein untuk komponen sistem BMP, termasuk ligan, reseptor dan faktor transduksi sinyal intraseluler telah ditunjukkan pada sel-sel pertumbuhan folikel (Otsuka et al., 2011). Secara khusus, GCs manusia mengekspresikan BMP2, BMP4, BMP6 dan BMP7. BMP2 dan BMP4 mengikat bone morphogenic protein tipe reseptor 1A (BMPR1A) dengan derajat afinitas yang berbeda yang berakibat memicu fosforilasi intraseluler small mother agains decapentaplegic (SMAD) jalur 1/5/8. Pada sel kultur wanita bersepeda, BMP6 dan BMP7 tapi tidak BMP4 dapat menurunkan basal 17 $\beta$-estradiol (E2) yang diproduksi oleh GCs (Khalaf et al., 2013). Paparan yang tidak seimbang pada BMP dapat mengubah sensitivitas folikel terhadap folikel stimulating hormone (FSH) dan dengan demikian dapat mengganggu proses seleksi folikel dominan (Khalaf et al., 2013). Selanjutnya, terapi GCs manusia dengan BMP2, BMP6 dan BMP7 secara signifikan menginduksi ekspresi AMH pada tingkat mRNA protein dan juga meningkatkan FSH reseptor (OguraNose et al., 2012).

Aktivin diproduksi oleh sel granulosa folikel primer sampai dengan folikel tersier, aktivin berfungsi untuk 
menginduksi pelepasan FSH dari hipofisis anterior dan pada ovarium, berperan dalam mempromosikan aktivitas aromatase, pembentukan rongga antral, dan proliferasi sel granulosa (Zhao et al., 2001). ActA (aktivin A) mengubah perkembangan folikel, menghasilkan peningkatan jumlah folikel preantral (Rosairo et al., 2008). Studi in vitro mengidentifikasi peran ActA (aktivin A) dalam transisi folikel primordial ke tahap perkembangan folikel primer dan menghambat apoptosis oosit dengan FSH sebagai stimulator (Cossigny et al., 2012).

Aktivin termasuk dalam kelompok superfamili transforming growth factor- $\beta$ (TGF- $\beta$ ) dan banyak diekspresikan di banyak jaringan, di mana mereka mengatur berbagai proses fisiologis, termasuk reproduksi (Knight dan Glister 2001; Knight dan Glister, 2006; Pang et al., 2016). Di ovarium, aktivin A diekspresikan dalam sel granulosa dan dapat bertindak mengatur fungsi ovarium secara autokrin atau parakrin, termasuk steroidogenesis, proliferasi sel granulosa, perkembangan folikel, pematangan oosit dan fungsi korpus luteum (Knight dan Glister, 2001; Pang et al., 2016). Aktivin memainkan peran penting dalam banyak proses fisiologis seperti diferensiasi dan remodeling sel, regenerasi dan perbaikan jaringan dari berbagai organ, angiogenesis, morfogenesis organ kelenjar, pluripotency dan diferensiasi germ cell, adhesi sel dan apoptosis. Aktivin berpartisipasi dalam proses reproduksi seperti embriogenesis, dalam ekspresi folikel stimulating hormon dan luteinizing hormon dan pematangan folikel ovarium (Ferreira et al., 2015).

Beberapa kelompok penelitian telah menunjukkan bahwa gen dan protein superfamili TGFB diekspresikan dalam jaringan ovarium (Ergin et al., 2008; Zhu et al., 2010; Hatzirodos et al., 2011; Nagashima et al., 2011). Penelitian terbaru menunjukkan bahwa morfologi dan tahap transisi genetik dari folikel primordial sampai ovulasi dan pembentukan korpus luteum berhubungan dengan aktivasi kaskade dari faktor pertumbuhan yang sangat mengatur proliferasi dan diferensiasi sel ovarium (Nagashima et al., 2011; Joseph et al., 2012; Kawano et al., 2012). Faktor pertumbuhan yang paling penting meliputi gen TGFB superfamili yang diekspresikan dalam sel somatik ovarium dan oosit mamalia, dengan demikian superfamili gen TGFB, berfungsi sebagai regulator intraovarian dari folikulogenesis (Paradis et al., 2009; Nagashima et al., 2011; Corduk et al., 2012). TGFB gen superfamili yang paling penting termasuk bone morphogenetic protein 2, 4, 5, 6, 7, dan 15 (BMP2, BMP4, BMP5, BMP6, BMP7, dan BMP15) dan growth diferentiation factor 9 (GDF9), yang diekspresikan melalui folliculogenesis dan mengatur langkahlangkah penting pertumbuhan dan pengembangan folikel (Knight dan Glister, 2006).

Peran ekspresi gen TGFB superfamily dalam pengaturan folliculogenesis tikus telah dipelajari dengan seksama menggunakan tikus model knockout(Li et al., 2012; Pangas et al., 2012). Drummond et al (2002) mempelajari peran TGFB / BMP atau jalur signaling aktivin di ovarium tikus postnatal dengan menggunakan tes ekspresi PCR real-time, mereka mengamati adanya reseptor aktivin atau BMP (ActRIA, ActRIB, ActRIIA, dan ActRIIB), betaglycan dan Smad 1-8 di dalam ovarium tikus. Ekspresi reseptor aktivin dan gen Smad superfamili umumnya terkait dengan pembentukan folikel sekunder. Pada tahap folikel antral, aktivitas reseptor dan Smad diekspresikan tergantung gen. Semua ekspresi gen aktivin-Smad superfamili teridentifikasi di 
dalam oosit pada semua tahap pengembangan folikel dan dalam sel granulosa dan sel teka. Hasil ini mengkonfirmasi bahwa TGFB, aktivin, Smad cascade signaling adalah kunci pengatur pertumbuhan dan perkembangannya folikel. Pertumbuhan dan perkembangan folikel diatur oleh sintesis dan sekresi beberapa growth factors yang dihasilkan oleh sel oosit atau granulosa. Faktor pertumbuhan ini disekresikan oleh oosit ke sel granulosa dan dengan sedemikian rupa mengaktifkan folikel melalui mekanisme parakrin yang spesifik. Beberapa penelitian telah menunjukkan peran faktor-faktor spesifik oosit yang dimiliki oleh TGFB superfamili termasuk BMP15 dan GDF9 (Piotrowska et al., 2013).

Pada banyak spesies mamalia GDF9 sangat penting untuk perkembangan folikuler awal melalui pengaruh langsung yang memungkinkan proliferasi dan diferensiasi pada sel granulosa (Castro et al., 2015). Defisiensi GDF9 terkait lagi dengan regulasi inhibin. Ekspresi normal GDF9 memungkinkan downregulation inhibin A dan dengan demikian meningkatkan kemampuan folikel untuk melewati tahap awal perkembangan (Otsuka et al., 2011). GDF9 menyebabkan perluasan sel kumulus, suatu proses karakteristik dalam perkembangan folikuler normal (Castro et al, 2015). GDF9 bertindak melalui dua reseptor pada sel-sel yang mengelilingi oosit, ia mengikat reseptor bone morphogenetic protein 2 (BMPRII) dan menuju ke hilir untuk mengaktifkan reseptor TGF- $\beta$ tipe 1 (Gilchrist et al, 2008). Aktivasi reseptor ligan memungkinkan fosforilasi dan aktivasi protein SMAD (Castro et al, 2015). Protein SMAD adalah faktor transkripsi yang ditemukan pada vertebrata, serangga dan nematoda, dan merupakan substrat antar sel dari semua molekul TGF- $\beta$ (Huang et al, 2009). GDF9 secara khusus mengaktifkan SMAD2 dan SMAD3 yang membentuk kompleks dengan SMAD4, mitra umum dari semua protein SMAD, yang kemudian dapat melakukan translokasi ke nukleus untuk mengatur ekspresi gen (Gilchrist et $a l, 2008)$.

BMP15 dapat bertindak tidak sesuai dengan GDF9 atau mungkin mengatur aktivitas GDF9 (You-Qiang et al., 2004; Reader et al., 2014). Penelitian in vitro telah menunjukkan bahwa ligan ini menggunakan jalur sinyal yang berbeda, sinyal BMP15 melalui jalur 1/5 SMAD, sementara sinyal GDF9 melalui SMAD 2/3 (Paradis et al., 2009; Li et al., 2014).

Semua bagian dari pohon kelor dapat dimakan dan sudah sejak lama dikonsumsi oleh manusia (Jed, 2005 dalam Krisnadi, 2015). Pohon kelor adalah salah satu tanaman yang paling luar biasa yang pernah ditemukan. Hal ini mungkin terdengar sensasional, namun faktanya memang kelor terbukti secara ilmiah merupakan sumber gizi berkhasiat obat yang kandungannya diluar kebiasaan kandungan tanaman pada umumnya. Sehingga kelor diyakini memiliki potensi untuk mengakhiri kekurangan gizi, kelaparan, serta mencegah dan menyembuhkan berbagai penyakit di seluruh dunia. Kelor benar-benar tanaman ajaib, dan karunia Tuhan sebagai sumber bergizi dan obat penyembuhan bagi umat manusia. Menurut Fuglie (1999) dalam Krisnadi (2015), menurut hasil penelitiannya, daun kelor ternyata mengandung vitamin $\mathrm{A}$, vitamin $\mathrm{C}$, Vit $\mathrm{B}$, kalsium, kalium, besi, dan protein, dalam jumlah sangat tinggi yang mudah dicerna dan diasimilasi oleh tubuh manusia, jumlahnya berlipat-lipat dari sumber makanan yang selama ini digunakan sebagai sumber nutrisi untuk perbaikan gizi di banyak belahan negara. Tidak 
hanya itu, kelor pun diketahui mengandung lebih dari 40 antioksidan.

Antioksidan adalah zat kimia yang membantu melindungi tubuh dari kerusakan sel-sel oleh radikal bebas. Kelor mengandung 46 antioksidan kuat, senyawa yang melindungi tubuh terhadap efek merusak dari radikal bebas dengan menetralkannya sebelum dapat menyebabkan kerusakan sel dan menjadi penyakit. Senyawa antioksidan yang terkandung dalam kelor adalah vitamin A, vitamin $\mathrm{C}$, vitamin $\mathrm{E}$, vitamin $\mathrm{K}$, vitamin $\mathrm{B}$ (choline), vitamin B1 (thiamin), vitamin B2 (riboflavin), vitamin B3 (niacin), vitamin B6, alanine, alpha-carotene, arginine, beta-carotene, beta-sitosterol, caffeoylquinic acid, campesterol, carotenoids, chlorophyll, chromium, delta5-avenasterol, delta-7-avenasterol, glutathione, histidine, indole acetic acid, indoleacetonitrile, kaempferol, leucine, lutein, methionine, myristic-acid, palmiticacid, prolamine, proline, quercetin, rutin, selenium, threonine, tryptophan, xanthins, xanthophyll, zeatin, zeaxanthin, zinc.

Efek anti inflamasi moringa oleifera melalui LPS yang diinduksi RAW 264.7 magrofag (Arulselvan et al, 2016). Pemberian ekstrak metanol moringa oleifera dapat menurunkan kadar TNF- $\alpha$ dan IL-6 pada dosis 20mg/kg/BB/hari (Endang dan Sukma, 2016). Menurut penelitian Moustafa et al, (2015) diperoleh hasil bahwa pemberian TAA pada tikus albino betina menyebabkan peningkatan serum TNF- $\alpha$ dan TGF- $\beta$ yang signifikan dibandingkan dengan kontrol. Pemberian ekstrak etanol daun kelor Moringa oleifera (MOE) dan atau LDR telah menurunkan secara signifikan kenaikan ini $(\mathrm{P}<0,05)$. Ekstrak daun kelor dapat menurunkan aktivitas NF-KB pada sel MCF-7 dibandingkan dengan kontrol. Penurunan aktivitas NF-kB dengan dosis IC50 2200 $\mu \mathrm{g} / \mathrm{ml}$ sebanyak $31,6 \%$ dan dosis 2 IC50
$4400 \mu \mathrm{g} / \mathrm{ml}$ sebanyak 36,5\%. Secara deskriptif ekstrak daun kelor cenderung meningkatkan apoptosis sel MCF-7 (Nabila dkk., 2016).

Penelitian Hasan et al, (2016) bertujuan untuk mengevaluasi efek ekstrak metanol dari Moringa oleifera (MO) dan atau dosis rendah radiasi gamma (LDR) terhadap toksisitas paru-paru pada tikus dengan amiodarone (AMD). Pemberian MO menyebabkan penurunan yang signifikan pada kadar tumor nekrosis faktor alfa (TNF- $\alpha$ ) dan tingkat faktor pertumbuhan beta (TGF- $\beta$ ) serta aktivitas laktat dehidrogenase (LDH). Selain itu, kandungan malondialdehid (MDA) dan hydroxyproline (HYP) secara signifikan menurun pada jaringan paru-paru. Selanjutnya, MO secara signifikan meningkatkan kandungan glutathione (GSH) yang berkurang di jaringan paruparu dibandingkan dengan AMD. Investigasi histopatologis jaringan paru menunjukkan adanya pneumonia interstisial pada tikus yang diobati dengan AMD. Pemberian oral Moringa oleifera dan atau paparan LDR membalikkan perubahan biokimia dan histopatologis yang diinduksi oleh AMD. Hal ini dapat dikatakan bahwa MO dan LDR mungkin memiliki peran yang cukup besar dalam pencegahan toksisitas paru-paru yang diinduksi oleh AMD. Kuersetin dan catenin menghambat ekspresi integrin, COX-2, TNF- $\alpha$, IL-1 $\beta$, MCP-1 (Huang et al., 2006), $\alpha \mathrm{V} \beta 1$ integrin (Doersch dan Newell-Rogers, 2017).

Berbagai penelitian mengenai khasiat tanaman kelor telah banyak disitasi. Sashidara dkk, (2009) melaporkan efek antiinflamasi dan antinosiseptik bagian akar tanaman kelor. Kelor juga dilaporkan memberikan aktivitas sebagai hepatoprotektif dan antibiotik (Eleirt, 2007). Ekstrak etanol daun kelor yang dikombinasi dengan 5-flourourasil 
dilaporkan sebagai kemoterapi pada sel kanker kolon (Nur, 2011). Kelor juga dilaporkan memiliki aktivitas kemopreventif (Barali, 2003) serta sebagai antiinflamasi, antispasmodik, antidiuretik, penurun kolesterol, antioksidan, antidiabetes dan antifungi.

\section{METODE PENELITIAN}

Penelitian ini berjenis penelitian eksperimental laboratorium dan rancangan yang dipakai adalah Randomized post test only control group design yaitu dengan cara membandingkan hasil observasi pada kelompok kontrol dan perlakuan setelah diberi tindakan. Pengelompokan sampel penelitian dilakukan secara simple random.

Sampel yang digunakan adalah mencit betina usia 3 bulan, berat badan mencit 20-25 gram sebanyak 12 sampel tiap kelompok. Kelompok terdiri dari kelompok kontrol dan kelompok perlakuan. Mencit disuntik siklosporin A secara intramuscular pada paha mencit dengan dosis $10 \mathrm{mg} / \mathrm{kgBB}$. Selanjutnya dilakukan penyuntikan jaringan endometrium. Bahan jaringan endometrium diambil secara exsisi dari uterus pasien operasi tumor jinak. Dosis yang diberikan pada mencit $0,1 \mathrm{ml}$. Dilakukan penyuntikan intraperitonium jaringan endometrium secara perlahan. Berikutnya dilakukan pemberian ethynil estradiol secara intramuscular pada paha mencit dosis $30 \mathrm{ug} / \mathrm{kgBB}$. Penyuntikan ethynil estradiol secara intramuscular pada paha mencit dilakukan pada hari pertama dan kelima setelah perlakuan endometrium. Hari ke-14 diharapkan telah menjadi mencit model endometriosis. Kelompok perlakuan diberikan ekstrak etanol daun kelor selama 14 hari. Sampel diambil segera setelah mencit dikorbankan dengan dislokasio servikalis, kemudian dilakukan pembedahan perut mencit untuk mengambil jaringan ovarium mencit. Sampel dari hasil eksisi implan endometriosis diletakkan pada cawan yang mengandung PBS, defikasi dan dehidrasi dalam aseton pada suhu $-20^{\circ} \mathrm{C}$ selama 20 jam, dilakukan penjernihan dengan metil benzoat dan xylene. Sampel dipenetrasikan (impregnasi) dengan parafin. Blok parafin yang dihasilkan disimpan pada suhu $4^{\circ} \mathrm{C}$ sampai dilakukan penyayatan jaringan. Sampel pada blok parafin dilakukan penyayatan serial sebanyak 5 set ketebalan masing-masing $100 \mu \mathrm{m}$. Pada sediaan sayatan pertama dari masing-masing set yang telah disiapkan dilakukan pengecatan dengan hematoxylin-eosin (HE). Pengacatan HE dimaksudkan untuk mendapatkan gambaran folikulogenesis pada jaringan ovarium secara mikroskopis.

Analisis deskriftif dilakukan untuk mengetahui distribusi frekuensi dari nilai rata-rata jumlah folikel sekunder, tersier dan folikel de Graaf pada kelompok perlakukan dan kelompok kontrol. Data diuji dengan uji normalitas dengan uji Shapiro Wilk dan uji homogenitas dengan uji Levene untuk menentukan data berdistribusi normal atau tidak berdistribusi normal. Data berdistribusi normal maka dilakukan uji komparasi antar kelompok pada variabel penelitian dengan menggunakan uji independent $t$ test. Data tidak berdistribusi normal maka dilakukan uji komparasi antar kelompok pada variabel penelitian dengan Mann Whitney U test.

\section{HASIL DAN PEMBAHASAN}

Tabel 1. Rerata dan simpangan baku folikel mencit model endometriosis antara kelompok kontrol (X1) dan kelompok 
Jurnal Biosains Pascasarjana Vol. 19 (2017) pp

(C) (2017) Sekolah Pascasarjana Universitas Airlangga, Indonesia

yang mendapat ekstrak etanol daun kelor (X2)

\begin{tabular}{ccc}
\hline \multicolumn{3}{c}{ Rerata dan Simpangan Baku } \\
\hline & X1 & X2 \\
\hline $\begin{array}{l}\text { Folikel } \\
\text { Primer }\end{array}$ & $1,61 \pm 1,06$ & $2,66 \pm 1,26$ \\
Folikel & $0,96 \pm 0,76$ & $1,43 \pm 0,70$ \\
$\begin{array}{c}\text { Sekunder } \\
\text { Folikel }\end{array}$ & $0,59 \pm 0,91$ & $1,25 \pm 1,06$ \\
Tersier & & \\
Folikel de & $0,02 \pm 0,08$ & $0,26 \pm 0,38$ \\
graaf & & \\
\hline
\end{tabular}

Berdasarkan hasil penghitungan rerata jumlah folikel primer, jumlah folikel sekunder, folikel tersier dan folikel de Graaf menunjukkan perbedaan yang bermakna antara kelompok kontrol dan kelompok perlakuan yang diberi ekstrak kelor $0,35 \mathrm{mg} / \mathrm{gBB}$. Dari tabel 1 dapat diketahui jumlah folikel primer, folikel sekunder, tersier dan de graaf secara signifikan lebih tinggi dibandingkan dengan kelompok kontrol. Hasil uji statistik pada indeks folikulogenesis menunjukkan hasil signifikan dengan masing-masing hasil signifikasi sebagai berikut : jumlah folikel primer $(0,038)$, jumlah folikel sekunder $(0,049)$, jumlah folikel tersier $(0,048)$ dan jumlah de Graaf $(0,026)$ hal ini menunjukkan bahwa ada perbedaan bermakna indeks folikulogenesis antara kelompok yang diberi ekstrak etanol Moringa oleifera dengan kelompok kontrol.

Lesi endometriosis berhubungan dengan peningkatan risiko infertilitas atau nyeri pelvis kronis (Bulun, 2009). Peradangan yang terlibat dalam endometriosis dapat merangsang ujung saraf di panggul dan dengan demikian menyebabkan rasa sakit, merusak fungsi rahim, mengurangi reseptivitas endometrium dan menghambat perkembangan oosit dan embrio (Berkley et al., 2004; Banhardt et al., 2002). Profil gene expression endometrium dari wanita dengan endometriosis terkait dengan kegagalan implantasi, infertilitas, dan resistensi progesteron (Kao et al., 2003; Burney et al., 2007). Jaringan endometriotik mempunyai ciri-ciri peradangan yang dikaitkan dengan kelebihan produksi prostaglandin, metaloproteinase, sitokin, dan kemokin (Guidice dan Kao, 2004; Sharpe-Timms, 2002). Peningkatan tingkat inflamasi akut akan meningkatkan sitokin seperti interleukin-1 $\beta$, interleukin-6, dan faktor tumor nekrosis, peningkatan sitokin meningkatkan adesi jaringan fragmen endometrium ke permukaan peritonium dan membran metaloproteinase proteolitik meningkatkan implantasi fragmen (Guidice dan Kao, 2004; Sharpe-Timms, 2002).

Pemberian ekstrak etanol moringa oleifera sebagai terapi yang mempunyai kandungan antiinflamsi (Singh et al., 2012; Anwar, 2006). Ekstrak etanol Moringa oleifera yang mempunyai kandungan flavonoid dengan senyawa aktif kuersetin sebagai antiinflamasi dan imunodulator. Kuersetin sangat mengurangi aktivasi ERK kinase dan p38 MAP kinase. Selain itu, kuersetin menghambat aktivasi $\mathrm{NF}-\kappa \mathrm{B}$ melalui stabilisasi NF- $\kappa \mathrm{B} / \mathrm{I} \kappa \mathrm{B} \quad$ kompleks, degradasi $\mathrm{I} \kappa \mathrm{B}$, sitokin proinflamasi dan ekspresi NO/iNOS (Yeon Cho et al., 2003).

Pengaruh parakrin intraovarian sangat penting untuk modulasi oosit, pertumbuhan dan pematangan folikel dan memberikan sensitifitas yang cukup terhadap stimulasi gonadotropin. Signalling antara oosit dan GCs belum sepenuhnya dipahami namun dalam beberapa tahun terakhir beberapa sinyal sudah dapat diidentifikasi beserta karakteristik fungsinya. Dalam konteks parakrin intraovarian, beberapa anggota 
transforming growth factor beta (TGF- $\beta$ ) superfamili diketahui memainkan peran penting (Sanchez et al., 2016). TGF- $\beta$ adalah peptida yang diproduksi secara eksklusif oleh GCs pada folikel pre-antral dan folikel antral kecil yang tumbuh, peptida ini berfungsi untuk menjaga ketenangan mereka (Sanchez et al., 2013).

Beberapa kelompok penelitian telah menunjukkan bahwa gen dan protein superfamili TGFB diekspresikan dalam jaringan ovarium (Ergin et al., 2008; Zhu et al., 2010; Hatzirodos et al., 2011; Nagashima et al., 2011). Penelitian terbaru menunjukkan bahwa morfologi dan tahap transisi genetik dari folikel primordial sampai ovulasi dan pembentukan korpus luteum berhubungan dengan aktivasi kaskade dari faktor pertumbuhan yang sangat mengatur proliferasi dan diferensiasi sel ovarium (Nagashima et al., 2011; Joseph et al., 2012; Kawano et al., 2012). Faktor pertumbuhan yang paling penting meliputi gen TGFB superfamili yang diekspresikan dalam sel somatik ovarium dan oosit mamalia, dengan demikian superfamili gen TGFB, berfungsi sebagai regulator intraovarian dari folikulogenesis (Paradis et al., 2009; Nagashima et al., 2011; Corduk et al., 2012). Drummond et al (2002) mempelajari peran TGFB / BMP atau jalur signaling aktivin di ovarium tikus postnatal dengan menggunakan tes ekspresi PCR real-time, mereka mengamati adanya reseptor aktivin atau BMP (ActRIA, ActRIB, ActRIIA, dan ActRIIB), betaglycan dan Smad 1-8 di dalam ovarium tikus. Ekspresi reseptor aktivin dan gen Smad superfamili umumnya terkait dengan pembentukan folikel sekunder. Pada tahap folikel antral, aktivitas reseptor dan Smad diekspresikan tergantung gen. Semua ekspresi gen aktivin-Smad superfamili teridentifikasi di dalam oosit pada semua tahap pengembangan folikel dan dalam sel granulosa dan sel teka. Hasil ini mengkonfirmasi bahwa TGFB, aktivin, Smad cascade signaling adalah kunci pengatur pertumbuhan dan perkembangannya folikel. Pertumbuhan dan perkembangan folikel diatur oleh sintesis dan sekresi beberapa growth factors yang dihasilkan oleh sel oosit atau granulosa. Faktor pertumbuhan ini disekresikan oleh oosit ke sel granulosa dan dengan sedemikian rupa mengaktifkan folikel melalui mekanisme parakrin yang spesifik. Beberapa penelitian telah menunjukkan peran faktor-faktor spesifik oosit yang dimiliki oleh TGFB superfamili termasuk BMP15 dan GDF9 (Piotrowska et al., 2013).

Dari beberapa penelitian diatas menjadikan alasan mengapa ekstrak etanol moringa oleifera Lam dapat meningkatkan folikulogenesis yaitu dipengaruhi oleh ekspresi aktivin dan komunikasi antara sel granulosa, sel teka dan oosit secara autokrin dan parakrin.

\section{KESIMPULAN DAN SARAN}

Kesimpulannya, pada kelompok mencit model endometriosis yang diberi ekstrak etanol daun kelor meningkatkan folikulogenesis dengan dosis 0,35 $\mathrm{mg} / \mathrm{gBB}$. Perlu dilakukan penelitian untuk mengevaluasi sel teka, sel granulosa dan oosit pada setiap fase perkembangan folikel.

\section{UCAPAN TERIMA KASIH}

Saya sangat berterima kasih kepada dokter, embriolog, patolog dari RSUD Sutomo Surabaya dan Fakultas Kedokteran Hewan Universitas Airlangga atas bantuan mereka dalam mengadakan penelitian ini. Saya mengucapkan terima 
Jurnal Biosains Pascasarjana Vol. 19 (2017) pp

(C) (2017) Sekolah Pascasarjana Universitas Airlangga, Indonesia

kasih yang tak terhingga kepada Yayasan

dan Stikes Ngudia Husada Madura atas 
bantuan finansial yang diberikan dalam penelitian ini.

\section{DAFTAR PUSTAKA}

Anwar, F., S. Latif., M. Ashraf., and A. H. Gilani. 2007. 'Moringa oleifera: A Food Plant with Multiple Medicinal Uses'. Phytotherapy Research. 21:17-25.

Berkley, K. J., A. J, Rapkin., and R. E, Papka. 2004. The pains of endometriosis. Science. 308:1587-9.

Bulun. S. E. 2009. 'Mechanisms of Disease Endometriosis'. The new england journal o $f$ medicine. 360:268-79.

Burney. R. O., and L. C. Giudice. 2012. 'Pathogenesis and pathophysiology of endometriosis'. Fertility and Sterility. 98(3) :511-519.

Cao. Y., Meng-fei. Z., Y. Yang, Shu-wu. X., Jin-gang. C, L. Cao., Ting-ting Z., and Yan. Z. 2014. 'Preliminary Study of Quercetin Affecting the Hypothalamic-Pituitary-Gonadal Axis on Rat Endometriosis Model'. Hindawi Publishing Corporation Evidence-Based Complementary and Alternative Medicine. 2014.

Dunlop, C. E., and R. A. Anderson. 2014. 'The regulation and assessment of follicular growth'. Scandinavian Journal of Clinical and Laboratory Investigation. 74(244): 13-17.

Ferreira, N. de Souza., M. C. de Almeida., G. W. de Araujo., R. M. de Melo Leite., I. C. dos Santos., M. de Paula Lima., and J. L. Pesquero. 2015. High Levels Production of Recombinant Human Activin AEffect upon in Vivo Follicle Stimulation. Advances in Bioscience and Biotechnology. 6 :96-104.

Giudice, L. C.., and L. C. Kao. 2004. 'Endometriosis'. (364): 1789-1799
Hasan, H. F., N. M. Thabet., and M. Kh. Abdel-rafei. 2016. 'Methanolic extract of moringa oleifera leaf and low doses of gamma radiation alleviated amiodarone-induced lung toxicity in albino rats'. Arch. Biol. Sci., belgrade. 68(1), 31-39.

Hendarto, H., P. Prabowo., F. A. Moeloek., S. Soetjipto. 2010. 'Growth differentiation factor 9 concentration in the follicular fluid of infertile women with endometriosis'. Fertil Steril. 94:758-60.

Hsueh, A. J. W., K. Kawamura., Y. Cheng., and B. C. J. M. Fauser. 2014. 'Intraovarian control of early folliculogenesis'. Endocrine society. Huang, H. J., J. C.Wu., P. Su., O. Zhirnov., W. L. Miller. 2001. A novel role for bone morphogenetic proteins in the synthesis of folliclestimulating hormone. Endocrinology. 142 :2275-2283.

Kipp, J. L., S. M. Kilen., T. K. Woodruff., and K. E. Mayo. 2007. 'Activin Regulates Estrogen Receptor Gene Expression in the Mouse Ovary'. The Journal of Biological Chemistry . 282 (50): 36755-36765.

Knight, P. G., and C. Glister. 2001. 'Potential local regulatory functions of inhibins, activins and follistatin in the ovary'. Reproduction. 121(4):503-12.

Knight, P. G., and C. Glister. 2006. 'Focus on TGF-b Signalling TGF-b superfamily members and ovarian follicle development'. Society for Reproduction and Fertility. 17417899

Matarese, G., G. De Placido., Y. Nikas., and C. Alviggi. 2009. 'Pathogenesis of endometriosis: natural immunity dysfunction or autoimmune 
disease'. Trends Mol Med. 9(5):2238.

Meuleman. C., B. Vandenabeele., S. Fieuws., C. Spiessens., D. Timmerman., and T. D'Hooghe. $2009 . \quad$ 'High prevalence of endometriosis in infertile women with normal ovulation and normospermic partners'. Fertility and Sterility. 92(1).

Moustafa, E. M., M. K. Abdel-Rafei., N. M. Thabet., and H. F. Hasan. 2015. 'Moringa oleifera Leaf Ethanolic Extract Subsidized by Low Doses of Gamma Irradiation Modulates the Thioacetamide Induced Fibrotic Signs in Liver of Albino Rats'. Pakistan J. Zool. 47(3):793-802.

Nagashima, T., J. Kim., Q. Li., J. P. Lydon., F. J. Demayo., K. M. Lyons., and M. M. Matzuk. 2011. Connective tissue growth factor is required for normal follicle development and ovulation. Mol Endocrinol. 25:1740-1759.

Pang, P. L., C. Hsun-Ming., C. JungChien., and L. C. K. Peter. 2016. 'Activin A upregulates PTGS2 expression and increases PGE2 production in human granulosalutein cells'. Reproduction. 152: 655-664.

Pauklin, S., and L. Vallier. 2015. 'Activin/Nodal signalling in stem cells'. Development. 142 (4): 607626.

Peng. J., Q. Li., K. Wigglesworth., A. Rangarajan., C. Kattamuri., R. T. Peterson., J. J. Eppig., T. B. Thompson., and M. M. Matzuk. 2013. 'Growth differentiation factor 9:bone morphogenetic protein 15 heterodimers are potent regulators of ovarian functions'. PNAS.

Piotrowska, H., B. Kempisty., P. Sosinska., S. Ciesiolka., D.
Bukowska., P. Antosik., M. Rybska., K.P. Brussow., M. Nowicki., M. Zabel. 2013. 'The role of TGF superfamily gene expression in the regulation of folliculogenesis and oogenesis in mammals'. Veterinarni Medicina. 58(10): 505515.

Pizzo, A., F. M. Salmeri., F. V. Ardita., V. Sofo., M. Tripepi., S. Marsico. 2002. 'Behaviour of Cytokine Levels in Serum and Peritoneal Fluid of Women with Endometriosis'. Gynecol Obstet Invest. 54:82-87.

Platteeuw, A. R., T. M. D'Hooghe., A. Fazleabas. 2014. 'Defining future directions for endometriosis research: workshop report from the 2011 world congress of endometriosis in Montpellier, France," Reproductive Science. 20:483-499.

Robertson, D. M., H. G. Burger., and P. J. Fuller. 2004. 'Inhibin/activin and ovarian cancer'. Endocrine-Related Cancer Bioscientifica. 11(1): 35-49.

Sanchez. A.M., P. Vigano., E. Somigliana., P. Panina-Bordignon., P. Vercellini., and M. Candiani. 2014. 'The distinguishing cellular and molecular features of the endometriotic ovarian cyst: from pathophysiology to the potential endometrioma-mediated damage to the ovary'. Human Reproduction Update. 20(2): 217-230.

Sanchez, A. M., E. Somigliana., P. Vercellini., L. Pagliardini., M. Candiani., $\quad$ P. Vigano. 2015. 'Endometriosis as a detrimental condition for granulosa cell Steroidogenesis and development: from molecular Alterations to clinical impact'. Journal of Steroid 
Biochemistry and Molecular Biology.

Singh. G.P., R. Garg., S. Bharwaj., and S. K. Sharma. 2012. "Anti-Inflamatory Evaluation of Leaf extract of Moringa Oleifera. Pharmaceuntical and Scientific Innovasion.

Sharpe-Timms, K. L. 2005. 'Defining endometrial cells: the need for improved identification at ectopic sites and characterization in eutopic sites for developing novel methods of management for endometriosis'. Fertility and Sterility. 84(1): 35-37.

Vercellini, P., P. Viganò., E. Somigliana., and L. Fedele. 2014. 'Endometriosis: pathogenesis and treatment'. Nature Review Endocrinology. 10:261-275.

Yang, D. Z.., W. Yang., Y. Li., Z. He. 2013. 'Progress in understanding human ovarian folliculogenesis and its implications in assisted reproduction'. J Assist Reprod Genet. 30:213-219

Young, J. M., and A. S. McNeilly. 2012.

'Inhibin removes the inhibitory effects of activin on steroid enzyme expression and androgen production by normal ovarian thecal cells'. $J$ Mol Endocrinol. 48(1): 49-60.

Young, V. J., J. K. Brown., P. T. K. Saunders., and A. W. Horne. 2013. 'The role of the peritoneum in the pathogenesis of endometriosis'. Human Reproduction Update. 19(5):558-569.

Young, V. J., J. K. Brown., J. Maybin., P. T. Saunders., W. C. Duncan., A. W. Horne. 2014. Transforming growth factor- $\beta$ induced Warburg-like metabolic reprogramming may underpin the development of peritoneal endometriosis. $J$ Clin Endocrinol Metab. 99:3450-3459.
Young, V. J., S. F. Ahmad., J. K. Brown., W. C. Duncan., and A. W. Horne. 2016. 'ID2 mediates the transforming growth factor- $\beta 1$ induced Warburg-like effect seen in the peritoneumof women with endometriosis'. Molecular Human Reproduction. 22(9):648-654.

Young, V. J., S.F. Ahmad., W. C. Duncan., and A. W. Horne. 2017. 'The Role Of TGF-B In The Pathophysiology Of Peritoneal Endometriosis'. Human Reproduction Update: 112. 